\title{
Pilot Unit for Mining Waste Reduction Methods
}

\author{
Veiko Karu ${ }^{1}$, Tiit Rahe ${ }^{2}$, Erki Närep ${ }^{3}$, Vivika Väizene ${ }^{4}$, Juan da Costa ${ }^{5},{ }^{1-5}$ Tallinn University of Technology
}

\begin{abstract}
Oil shale mining is a crucially important industry for the Estonian economy. More than 85 percent of electricity in Estonia is produced from oil shale. The oil shale deposit is located in North-East Estonia. The oil shale bed descends three meters per kilometer to the south. The oil shale seam contains interlayered limestone. Some of it is used as low class aggregate rock and the rest is waste rock which is stored in waste rock heaps. Crushing, separating and sampling tests of the waste material are currently being carried out. Initial results show some developments of cutting and crushing possibilities. The aim of this study is to find technological solutions to oil shale waste rock reuse and improve current mining technology.
\end{abstract}

Keywords - pilot unit, crushing bucket, minijig, oil shale, enrichment, mining waste management

\section{INTRODUCTION}

The main mineral resource in Estonia is oil shale [14; 24]. There are also sufficient reserves of limestone and dolostone, peat, sand, gravel and clay. Phosphorite and granite are occurrences in the current economical situation in spite of the fact that phosphorite has been extracted for 70 years in former times. All previous mining activities have produced mining waste, for instance, the total volume of waste rock from oil shale mining is more than 76 million $\mathrm{m}^{3}$ and covers about 790 ha in Estonia [5; 17; 28].

Estonia is in a good position from the environmental point of view. Due to neutralizing alkaline limestone massive in all mining areas and not having acidic reactions, reclamation is easily done with the same equipment used in the mining processes. Water is purified in settling ponds and does not require additional chemical treatment. The main concern for underground mining is the ground stability of the room and pillar mining area $[7 ; 9 ; 10]$.

It is necessary to develop and implement new mining methods in order to mine oil shale more sustainably [25; 27]. At the same time ensure the stability of the ground. We need more knowledge about selective mining, waste usage and backfilling technologies in order to do so. Different laboratory investigations show that recycled crushed brick can be used as fill material according to their properties [1;2]. Oil shale waste rock properties are similar to crushed rock, crushed brick or limestone aggregate. Therefore we can also use oil shale waste rock as a fill material or as aggregate in some areas $[19 ; 29]$.

We have obtained new pilot equipment to test different possibilities of waste reduction technology. With the framework of Min-Novation project we have obtained a mini wheel loader, a crushing bucket and a minijig enrichment unit [8]. It is possible to discover new methods of usage and reduction of the already existing mining waste, using the new equipment along with other laboratory devices.
Previous tests with CDE fine separation equipment [3] were carried out in Estonia oil shale mine separation plant. The aim of these tests was to separate fine material from pulp before the material input to the sedimentation pond. An additive coagulant, which combined fine particles in a hydro cyclone, was added. As a result of these tests it was not possible to achieve higher oil shale calorific value with fine separation.

The most important new pilot equipment units are minijig enrichment unit, which is able to enrich large amounts of tested material using water and gravity; a high capacity sieve shaker and a mini wheel loader, which is capable to operate with different operating devices - crushing bucket, soil bucket, lifting crane and forklift.

Previous researches have studied and modeled oil shale deposits, described the potential technologies for environmentfriendly oil shale mining $[6 ; 13 ; 15 ; 21]$ and the usage of oil shale waste rock $[19 ; 18 ; 29]$. With the present study, we have reached the next stage where the described technologies can be tested on the laboratory level. Our aim is to test and develop optimal methods for selective material crushing and handling, using the previously mentioned equipment. The first tests have been carried out with oil shale waste rock using the new pilot units and in cooperation with ALLU crushing bucket manufacturers.

\section{METHODS}

Mining waste reduction methods include all mining processes from resource distribution to the final yield in the plant. A cooperation project for comparing and testing possibilities of mine waste reduction has been set up to create a transnational network with regional networks [8]. The activities carried out on the regional and transnational level will secure better access to knowledge, state-of-the-art technologies and good practice to small and medium sized enterprises active in the mineral waste management and prevention sector. The research study addresses all the waste management challenges and opportunities that face the mining industry of the Baltic Sea Region, which should be understood as an extension to all forms of extraction of natural nonrenewable resources [11].

\section{A. Pilot Unit}

In the mining industry it is necessary to use more environmental-friendly technologies. Investing in these technologies is always expensive. Decisions are based on economical calculations and studies on profitability. To ensure the efficiency of a certain technology, the pilot unit stage has to be carried out beforehand. During this stage, specific processes are observed.

The mining waste project MIN-Novation has taken oil shale waste crushing and limestone separation from oil shale under 
observation. In this case, the previously mentioned pilot unit equipment is obtained to carry out future tests. The following characteristics were followed in the compilation of the pilot unit: lifting capacity of the mini wheel loader, particle size of the crushed material, capacity of the sieving unit and the speed of the enrichment process.

Our crushing bucket is a bucket with two mounted rotary shafts which rotate in opposite directions to one another, crushing the material and releasing it from under the bucket. It can be used for thinning and mixing different materials, such as soil, compost, construction waste, glass, coal and limestone. Generally, crushing buckets can be used as an operating device for excavators and wheel loaders. The loading cycle is similar to any type of bucket with the exception of the crushing function. Crushing is achieved by sharp blades mounted on the rotary shafts. The crushing shafts are activated by hydraulic pressure. The bucket itself does not have any power source. Therefore it is necessary for the operation of the crushing bucket to be connected to a machine which has a hydraulic power output and a connecting plate, which enables the movement of the bucket. In our case, we have chosen the mini wheel loader Avant 745 (Fig. 1.).

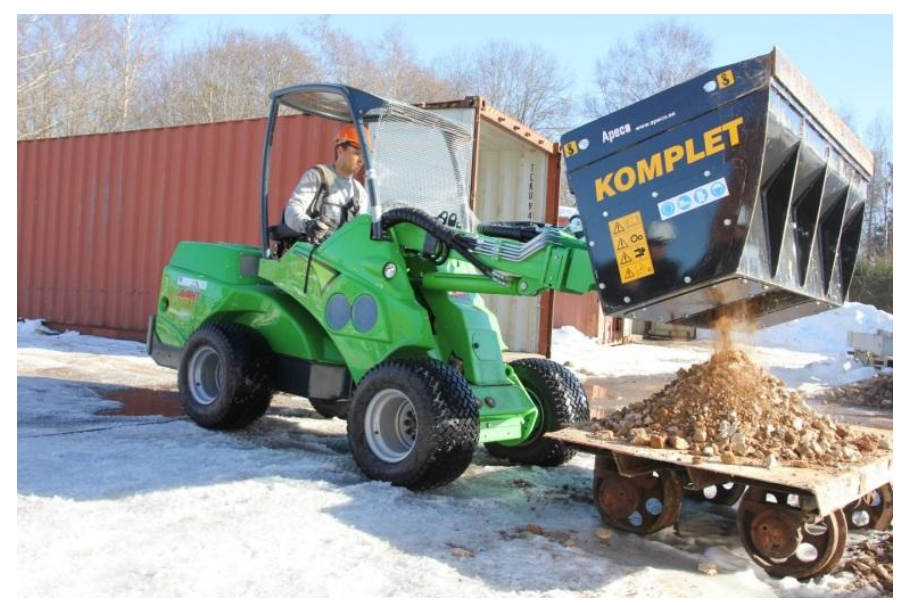

Fig. 1. Crushing bucket and mini wheel loader Avant 745

The advantage of crushing buckets over larger crushers is their mobility and small size, which means that they can work on site, even in underground conditions. It is possible to scoop, crush, transport, and load the material in one cycle. Selective crushing is based on the fact that oil shale is more fragile than limestone, meaning that oil shale breaks relatively quickly and into smaller fractions. The minijig enrichment unit, produced by AllMineral, is a gravitation enrichment unit. The enrichment process is based on the behavior of rock in the influence of gravity which is achieved by pulsating water. Fractions with higher density are separated from other fractions with the material being lifted up and down by water [4]. Therefore it is essential that the mineral and waste fractions have different densities. In addition to density, the particle size and shape is also crucial. Larger particles have a larger influence of gravity which reduces the enrichment efficiency and therefore it is recommended to use specified fractions with a smaller variety in particle size. In addition, round particles can move more freely compared to flat ones in the suspension since they are able to move through gaps between larger particles. The outcome of the enrichment process is material sedimentation into layers. The test container consists of plexiglass layers which can be separated layer by layer (Fig. 2.). In order to get the best results, it is necessary to observe the enrichment productivity and quality $[22,26]$ of each enriched layer to choose the right working mode during the enrichment process. The most precise stratification requires the amplitude and frequency of water pulsation to be optimized according to the sample characteristics.

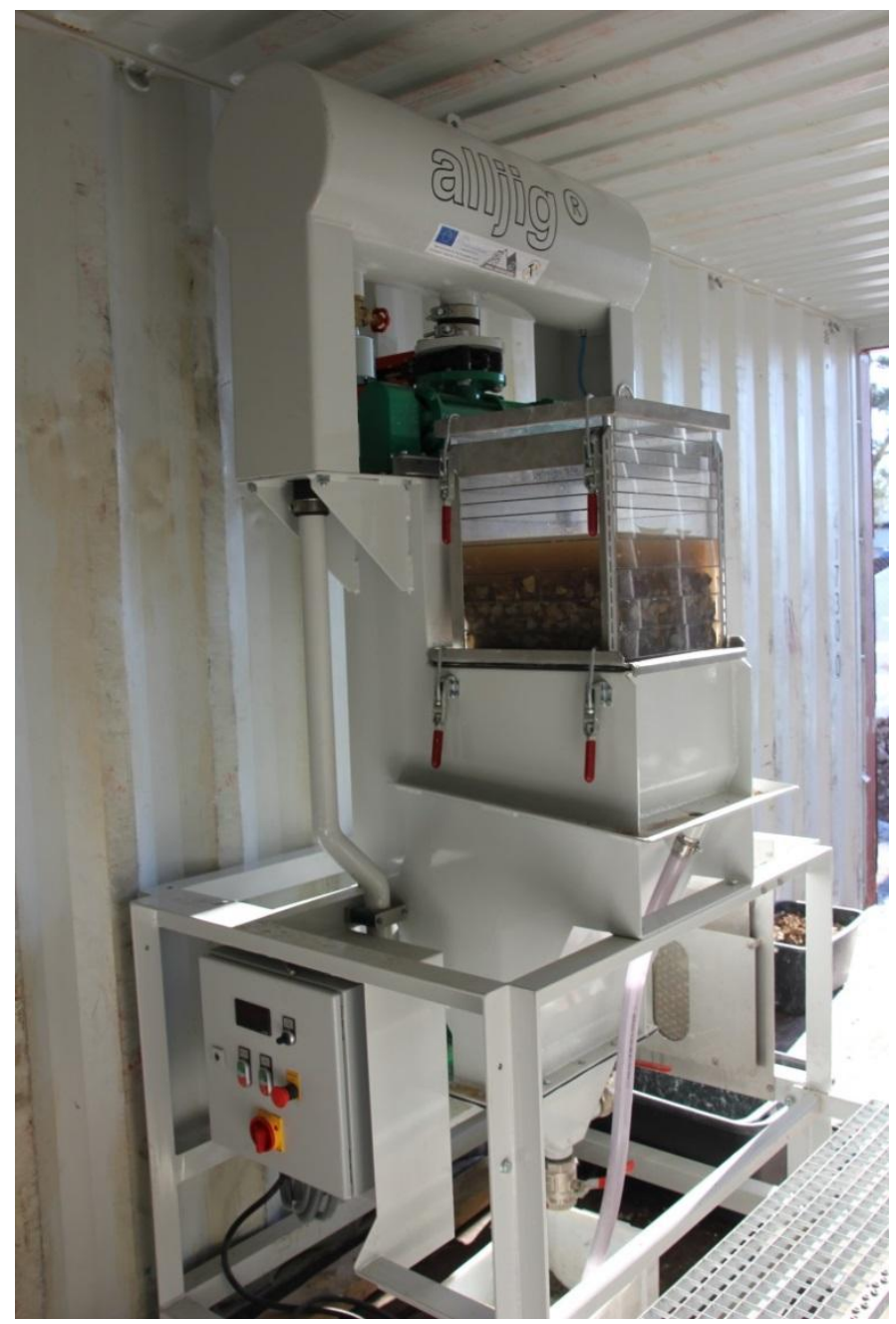

Fig. 2. Enrichment unit - minijig

In our conditions, the enrichment unit can be used to separate oil shale from limestone. Oil shale layers on top of limestone layers can be separated from each other and extracted selectively from the device as a result of the sedimentation process. This enables us to obtain the valuable mineral from waste landfills by crushing the material and separating it with the enrichment unit. Tests with the enrichment unit help us to examine and analyse the material processed with the crushing bucket. 


\section{B. Possible usage of waste}

The limestone layers in oil shale seam have a slightly lower quality compared to the yield extracted from limestone quarries. Regardless of the quality, the waste rock obtained from oil shale enrichment can still be used for beneficial purposes. In the construction industry, the waste rock can be used as filler material for constructions. Splinters produced from waste rock can be used as building material and the highquality component to produce concrete. In addition to that, the waste rock can be used in reclamation together with overburden or for backfilling in underground conditions [20]. A part of our study is to test the separated limestone together with oil shale ash and cement in concrete production. Our aim is to prove the beneficial potential of oil shale waste rock using necessary equipment to evaluate the properties of the produced concrete.

\section{RESUlTS}

For now we have carried out several test periods using the obtained pilot equipment. For instance, we have tested limestone clinker and gained grading curves from single and double crushing. In addition we have also tested the crushing bucket to crush oil shale waste rock and the enrichment unit to separate oil shale from limestone.

\section{A. Crushing bucket}

The first crushing bucket tests were carried out in collaboration with the manufacturers of ALLU crushing buckets. These tests showed that further study on the use of crushing buckets is indeed justified and it can provide us with new useful information (Fig. 3.). The necessary pilot equipment is acquired by the Department of Mining in order to carry out this study.

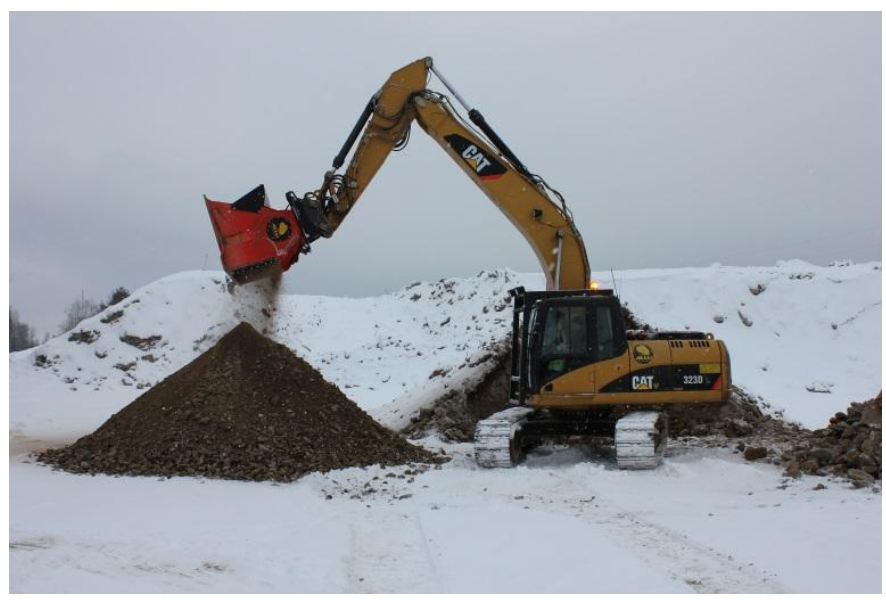

Fig. 3. ALLU crushing bucket test in Narva open cast

During the ALLU crushing bucket testing, carried out in 2011-2012, it was shown that the material is mixing inside the crushing bucket, whereas in our pilot unit, the material is solidly moving into the crushing shafts. Therefore it is not possible to separate limestone fractions while crushing. However, visual observation determined that the crushed oil shale fractions are indeed smashed to a greater extent compared to limestone, which allows us to separate oil shale from limestone using the screens as in the Allu crushing buckets tests. Grading analysis and fractionation of different classes of oil shale and limestone were carried out to describe the possibilities of enrichment of mined and crushed material with different properties using the screening method. Fig. 4. and Fig. 5. show the analysis results of the oil shale from Estonia mine material crushed by ALLU crushing buckets mark ALLU DH 3-17/X75.

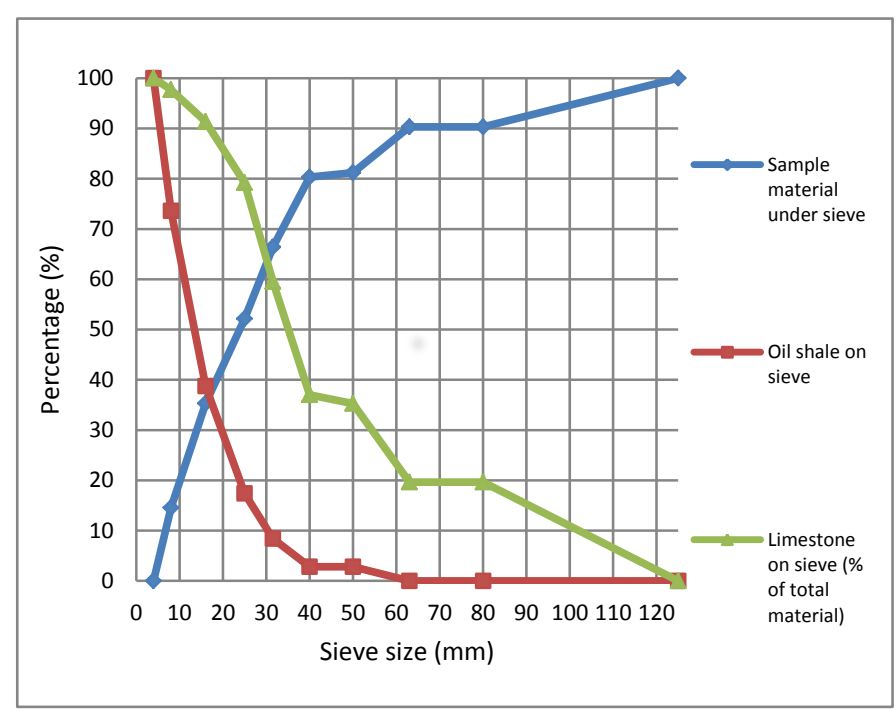

Fig. 4. Crushing bucket's grading and fraction analysis of processed material

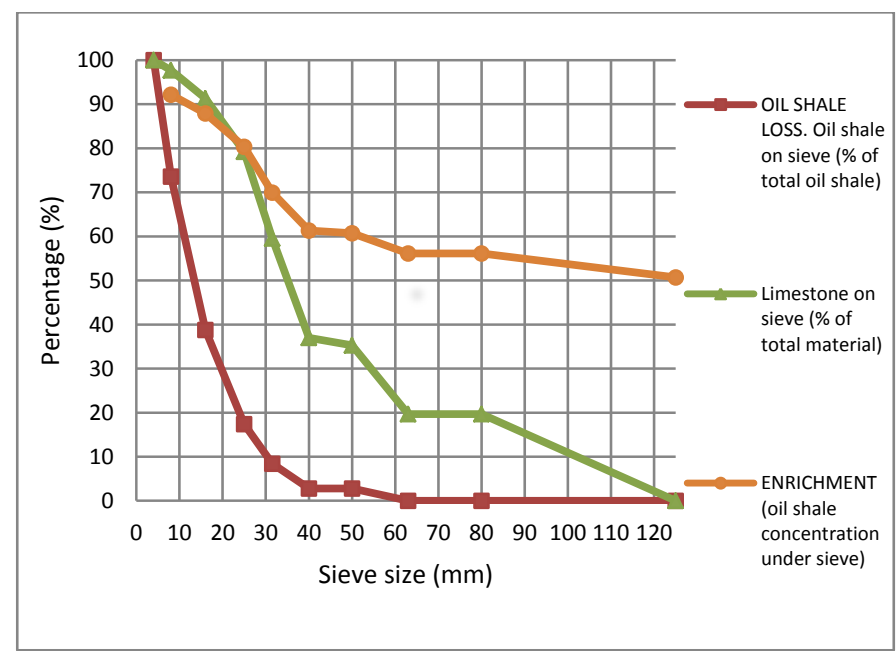

Fig. 5. Screening enrichment of crushing bucket's processed material

\section{B. Enrichment unit}

Currently, the oil shale in Estonia is enriched using heavy media separation (HMS) process. The enrichment unit we use is stratifying material with pulsating water. To test the capabilities of our enrichment unit, a test with mixed oil shale and limestone material has been carried out. The results were more or less successful, however, a few downsides were found as follows:

1. Every separation requires at least 30 to 40 liters of material. 
2. When processing material with variable particle size, smaller fractions can get stuck between larger fractions and may not stratify properly.

3. Material smaller than $1 \mathrm{~mm}$ cannot be processed since smaller particles are discharged with water.

4. After every enrichment process, there will always remain some material that includes both oil shale and limestone (Fig. 6. and Fig. 7.).

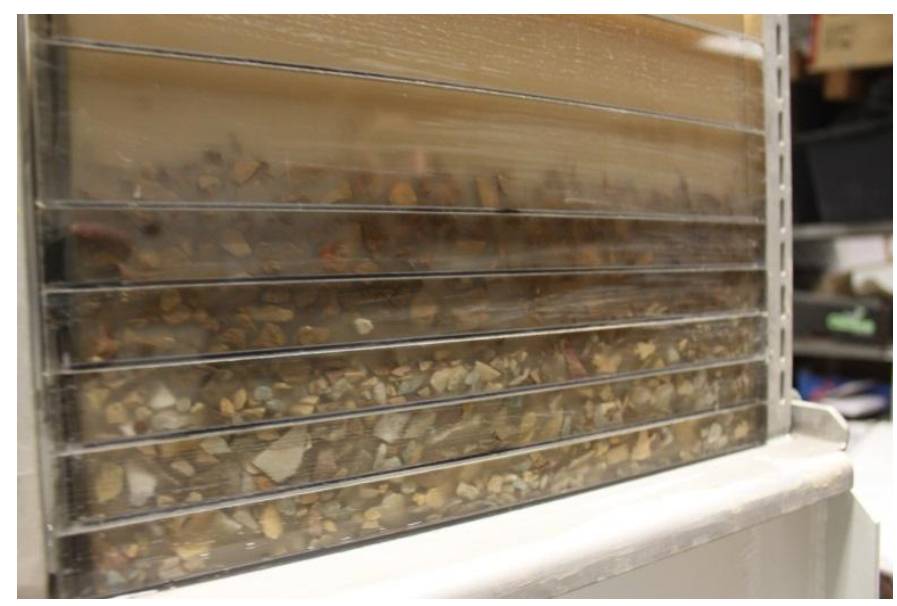

Fig. 6. Separating limestone and oil shale with minijig

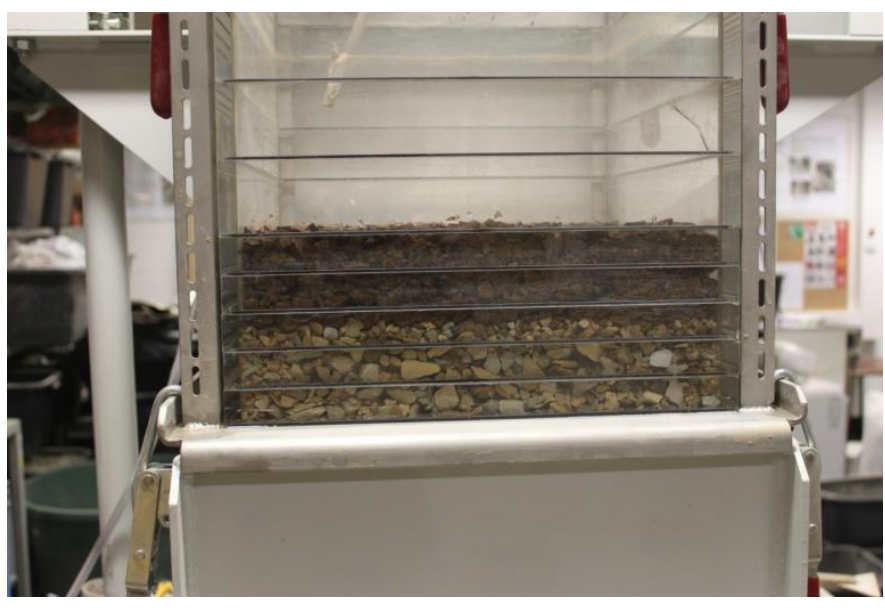

Fig 7. Separated material inside the minijig sample box before removal

\section{DISCUSSION}

\section{A. Crushing bucket}

Figures 4 and 5 show that this kind of processed material can be enriched rather well with screening, screening buckets or sieves with appropriate sieve sizes. For instance, if we screen the given material with a $25 \mathrm{~mm}$ sieve:

1. The yield under the sieve would be $52 \%$ of the initial material. If the material transported out of the mine consists solely of the yield under the sieve, the transported quantities will be reduced by $48 \%$, which, for instance, can later on be used with the introduction of backfilling technology to underpin shafts (Fig. 2.).

2. The oil shale loss in the processed material would be $17.4 \%$ (Fig. 2.).
3. We would be able to remove $79 \%$ of limestone from the mined material (Fig. 2.).

4. The concentration of oil shale in the given material would rise $30 \%$, resulting in the total oil shale concentration of $80 \%$ (Fig. 3.).

However, we should use $40 \mathrm{~mm}$ sieves if we concede to lose less than $3 \%$ of oil shale during the enrichment of the given material. This means that quantities transported from the mine would be reduced only by $20 \%$, the removal of limestone from mined material would be $37 \%$ and concentration of oil shale would rise from $50 \%$ to $61 \%$.

The selection of sieves during the enrichment of the processed material will be set by economic benefit.

The most important properties of the material in terms of crushing are moisture content, relation between limestone and oil shale concentrations, compression of oil shale and limestone, the difference between these compressions, etc.

In theory, if the crushing bucket operator is experienced, it is possible to remove some of the limestone as early as the end of the first crushing stage. The use of screening separates even more limestone from the crushed material. Oil shale fractions are smaller and can be screened out while limestone remains on the screen and can be extracted. It is possible to replace the standard buckets and crushers used in mines with crushing and screening buckets. Excavated material can be crushed to smaller fractions using the crushing bucket and then remove the fractions of limestone using the screening bucket. The remaining residual material can be used for backfilling during underground mining operations.

To introduce the usage of crushing buckets in the oil shale industry, more tests need to be carried out to prove the use of crushing buckets improving the sustainability and economic benefits of oil shale mining. The amounts of extracted material in the oil shale mining sector are enormous and small models are not capable to meet the needs. ALLU, the producer of crushing buckets, is developing high-dimensional crushing buckets with bucket volumes almost up to $6 \mathrm{~m}^{3}$. These new crushing buckets meet the requirements and can be used to replace the standard buckets on underground wheel loaders.

\section{B. Enrichment unit}

The most important properties of the processed material are density and particle size. In order to provide proper stratification, the feed material has to include material with different densities. In this study, limestone and oil shale have a large difference in their densities - limestone is almost twice as dense as oil shale.

The particles in the processed material have to be in similar size in order to gain satisfying results. This means a preliminary sieving has to be carried out before the enrichment process. Therefore it is necessary to sieve the material into fractions and enrich every fraction separately (Fig. 8.) to ensure proper feed material enrichment.

As a result of the stratification process there will always be some layers which are still mixed with both limestone and oil shale. To separate the whole mixed sample material, several processes have to be carried out with the same sample patch 
until the material is fully separated. There is always material loss in the enrichment processes, but our tests with the minijig show that a majority of mixed oil shale and limestone can indeed be fully separated.

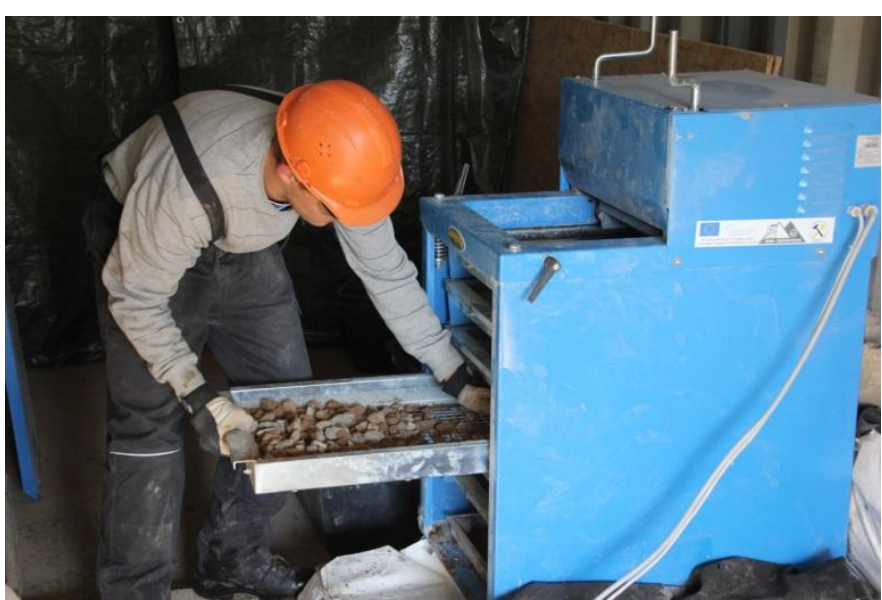

Fig. 8. Sieving for minijig

It is possible to save up from the transportation of extracted mineral if the primary enrichment is done near the mining face. Introduction of the backfilling technology helps to reduce ground stability issues $[12,16,23]$ and allows us to extract oil shale with smaller loss. It is necessary to proceed with the study in order to find optimal solutions of how and where to use crushing buckets.

In the future we hope to assist in finding new methods to reduce the existing mining waste by selective crushing, mine oil shale with smaller losses and recycle mining waste (oil shale waste rock, limestone fines, etc).

\section{V.CONCLUSION}

In addition to oil shale, the main mineral resource, there are sufficient reserves of limestone and dolostone, peat, sand, gravel and clay in Estonia.

Mining waste reduction methods include all mining processes from resource distribution to final yield in the plant. A cooperation project for comparing and testing possibilities of mine waste reduction has been set up to create a transnational network with regional networks. The activities carried out on the regional and transnational level will secure better access to knowledge, state-of-the-art technologies and good practice to small and medium sized enterprises active in the mineral waste management and prevention sector. The research study addresses all the waste management challenges and opportunities that face the mining industry of the Baltic Sea Region, which should be understood as an extension to all forms of extraction of natural non-renewable resources.

In order to carry out this study, the Department of Mining has obtained pilot units - crushing bucket with mini wheel loader, sieving unit and enrichment unit. Tests with pilot equipment have shown that the equipment has potential usage in the Estonian mining industry and it is necessary to continue the tests to further improve knowledge about the possibilities for the pilot unit.
Current directions of development include the replacement of standard buckets with crushing buckets in underground mining to reduce oil shale loss, enrichment of oil shale residual material to reduce mining waste, and producing profitable products using the separated limestone from oil shale waste heaps.

\section{ACKNOWLEDGEMENTS}

The research is supported by the MIN-NOVATION project - http://www.min-novation.eu; Energy Technology Program Sustainable and environmentally acceptable Oil shale mining No. 3.2.0501.11-0025 - mi.ttu.ee/etp; Doctoral School of Energy and Geotechnology II DAR8130/1.2.0401.090082 - mi.ttu.ee/doktorikool.

\section{REFERENCES}

1. Arulrajah, A.; Ali, M. M. Y.; Piratheepan, J.; Bo, M. W. (2012). Geotechnical properties of waste excavation rock in pavement subbase applications. Journal of Materials in Civil Engineering. Vol 24 (7), pp 924-932 http://dx.doi.org/10.1061/(ASCE)MT.1943-5533.0000419

2. Arulrajah, A.; Ali, M. M. Y.; Piratheepan, J.; Bo, M. W.; Sivakugan, N. (2012). Canadian Geotechnical Journal. Volume 49 (7). Pp 796-811 http://dx.doi.org/10.1139/t2012-041

3. CDE Mining. http://www.cdeglobal.com/projects/category/31/cdemining. (19.06.2013)

4. Jungmann, A.; Quindt, J. (1999). Alljig (R) - Technology for separation of building rubble and other secondary raw materials. Rewas '99 Symposium on recycling, waste treatment and clean technology. 1(3S), $367-379$.

5. Kahru, A.; Põllumaa, L. (2006). Environmental hazard of the waste streams of Estonian oil shale industry: An ecotoxicological review. Oil Shale, 23(1S), $59-93$

6. Karu, V. (2010). Spatial modelling tools in mining areas for improving mining process. Lahtmets, R. (Toim.). 8th International Symposium "Topical problems in the field of electrical and power engineering. Doctoral school of energy and geotechnology". II : Pärnu, Estonia, 11.01.-16.01.2010 (129 - 133). Tallinn: Elektriajam

7. Karu, V. (2010). Stability problems in undermined areas. Lahtmets, R. (Toim.). 8th International Symposium "Topical problems in the field of electrical and power engineering. Doctoral school of energy and geotechnology". II : Pärnu, Estonia, 11.01.-16.01.2010 (134 - 137). Tallinn: Elektriajam

8. Karu, V. (2011). European Union Baltic Sea region project "MINNOVATION". Oil Shale, 28(3), 464 - 465.

9. Karu, V. (2012). Dependence of land stability on applled mining technology. 11th International Symposium "Topical Problems in the Field of Electrical and Power Engineering", Doctoral Scholl of Energy and Geotechnology, Pärnu, Estonia, 16-21.01.2012 (252 255).Elektriajam

10. Karu, V. (2012). Potential Usage of Underground Mined Areas in Estonian Oil Shale Deposit. (PhD Thesis, Tallinn University of Technology, Faculty of Power Engineering,, Department of Mining)Tallinn University of Technology Press

11. Karu, V.; Valgma, I.; Rahe, T. (2013). Mining Waste Reduction Methods. Zakis, J. (Toim.). 13th International Symposium "Topical Problems in the Field of Electrical and Power Engineering", Doctoral Scholl of Energy and Geotechnology II, Pärnu, Estonia, 14-19.01.2013 (278 - 280). Tallinn: Elektriajam

12. Karu, V.; Västrik, A.; Anepaio, A.; Väizene, V.; Adamson, A.; Valgma, I. (2008). Future of oil shale mining technology in Estonia. Oil Shale, 25(2S), 125 - 134. http://dx.doi.org/10.3176/oil.2008.2S.04

13. Karu, V.; Västrik, A.; Valgma, I. (2008). Application of modelling tools in Estonian oil shale mining area . Oil Shale, 25(2S), 134 - 144.

14. Koitmets, K.; Reinsalu, E.; Valgma, I (2003). Precision of oil shale energy rating and oil shale resources. Oil Shale, 20(1), 15 - 24.

15. Nikitin, O.; Väli, E.; Pastarus, J.; Sabanov, S. (2007). The Surface Miner Sustainable Oil-shale Mining Technology Testing Results in Estonia. In: Proceedings of the Sixteenth International Symposium on Mine Planning and Equipment Selection (MPES 2007) and the Tenth 
International Symposium on Environmental Issues and Waste Management in Energy and Mineral Production (SWEMP 2007): Mine Planning and Equipment Selection and Environmental Issues and Waste Management in Energy and Mineral Production. Bangkok, Thailand, December 11-13, 2007. Reading Matrix Inc USA, 2007, 678 - 687.

16. Orru, M; Vaizene, V; Pastarus, J-R; Systra, Y; Valgma, I. (2013) Possibilities of oil shale mining under the Selisoo mire of the Estonia oil shale deposit. Environmental Earth Sciences, 2013, DOI 10.1007/s12665-013-2396-x http://dx.doi.org/10.1007/s12665-0132396-X

17. Puura, E. (1999). Technogenic minerals in the waste rock heaps of Estonian oil shale mines and their use to predict the environmental impact of the waste. Oil Shale, $16(2 \mathrm{~S}), 99-107$.

18. Tohver, T. (2010). Utilization of waste rock from oil shale mining. Oil

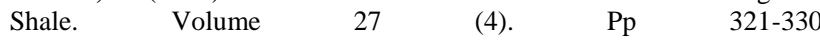
http://dx.doi.org/10.3176/oil.2010.4.05

19. Tohver, T. (2011) Utilization of Waste Rock from Oil Shale Mining (PhD Thesis, Tallinn University of Technology, Faculty of Power Engineering,, Department of Mining)Tallinn University of Technology Press

20. Väizene, V. (2009). Backfilling technologies for oil shale mines. Valgma, I. (Eds.). Resource Reproducing, Low-wasted and Environmentally Protecting Technologies of Development of the Earth Interior (1 pp.). Tallinn: Department of Mining TUT; Russian University of People Friendship

21. Valgma, I. (2009). Oil Shale mining-related research in Estonia. Oil Shale, 26(4), 445 - 150. http://dx.doi.org/10.3176/oil.2009.4.01

22. Valgma, I.; Karu, V.; Anepaio, A.; Väizene, V. (2007). Increasing oil shale quality for meeting EU environmental requirements. Mining and the Environment 2007 (195 - 205). Baia Mare: Freiberg TU

23. Valgma, I.; Karu, V.; Västrik, A.; Väizene, V. (2007). Future of oil shale mining. In: Georesources and public policy: research, management, environment : abstracts: 15th Meeting of the Association of European Geological Societies, Tallinn (Estonia), 16-20 September 2007. (Toim.) Hints, O.; Kaljo, S.. Tallinn: Eesti Geoloogia Selts, 2007, 81.

24. Valgma, I.; Karu, V.; Viil, A.; Lohk, M. (2007). Oil shale mining developments in Estonia as the bases for sustainable power industry. In: 4th International Symposium "Topical Problems in the Field of Electrical and Power Engineering" : Doctoral School of Energy and Geotechnology: 4th International Symposium "Topical Problems in the Field of Electrical and Power Engineering", Kuressaare, Estonia, 15. .20.01.2007. (Toim.) Lahtmets, R.. Tallinn: Tallinn University of Technology, Faculty of Power Engineering, 2007, 96 - 103.

25. Valgma, I.; Leiaru, M.; Karu, V.; Iskül, R. (2012). Sustainable mining conditions in Estonia. 11th International Symposium "Topical Problems in the Field of Electrical and Power Engineering", Doctoral Scholl of Energy and Geotechnology, Pärnu, Estonia, 16-21.01.2012 (229 - 238). Tallinn: Elektriajam

26. Valgma, I.; Reinsalu, E.; Sabanov, S.; Karu, V. (2010). Quality control of Oil Shale production in Estonian mines. Oil Shale, 27(3), 239 - 249. http://dx.doi.org/10.3176/oil.2010.3.05

27. Valgma, I.; Västrik, A.; Kõpp, V. (2010). Sustainable mining technologies for Estonian minerals industry. Lahtmets, R (Toim.). 9th International Symposium Pärnu 2010 "Topical Problems in the Field of Electrical and Power Engineering" and "Doctoral School of Energy and Geotechnology II”, Pärnu, Estonia, June 14 - 19, 2010 (69 - 73). Tallinn: Estonian Society of Moritz Hermann Jacobi

28. Väli, E.; Valgma, I.; Reinsalu, E. (2008). Usage of Estonian oil shale. Oil Shale, 25(2S), 101 - 114. http://dx.doi.org/10.3176/oil.2008.2S.02

29. Volokitin, G. G.; Skripnikova, N. K.; Volokitin O. G.; Volland, S. (2011). Technology for producing mineral fibers by recycling ash-sludge and oil-shale wastes. Glass and geramics, 68(7-8S), 239 - 241. http://dx.doi.org/10.1007/s10717-011-9362-4

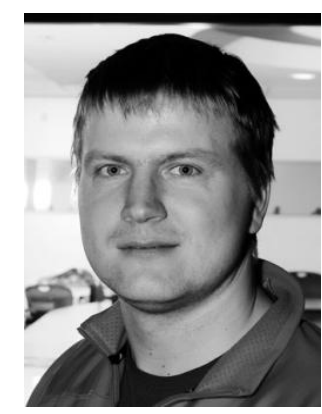

Veiko Karu is Teaching Assistant at Tallinn University of Technology, Department of Mining and MIN-NOVATION project Communication Manager. He obtained Ph. D. in Energy- and Geotechnology, year 2012 at Tallinn University of Technology. Research interest includes technological development, geothermal energy, oil shale mining developments, GIS technologies, modeling mining works.

He has been working in Department of Mining since 2005. He has been connected with various studies related with mineral extraction. $\mathrm{He}$ is member of Editorial Board of Inseneeria journal, member of Estonian Mining Society, member of the Society of Mining Professors.

Address: Ehitajate tee 5, 19086, Tallinn, Estonia

E-mail: veiko.karu@ttu.ee

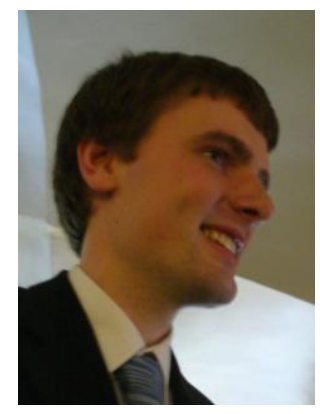

Tiit Rahe obtained his Bachelor of Science degree in Geology. Currently he is doing his Master degree (MSc) in Geotechnology. Research interests are GIS technologies, computer modeling, sustainable mining methods and mining waste reduction technologies.

$\mathrm{He}$ is specialist in Department of Mining at Tallinn University of Technology. In Department of Mining he has been working since 2012. In 2011 he has worked Tartu University.

Tiit Rahe is a founding member of the Estonian Internet Community and was board member of Tartu Student Nature Protection Circle.

Address: Ehitajate tee 5, 19086, Tallinn, Estonia

E-mail: tiit.rahe@ttu.ee

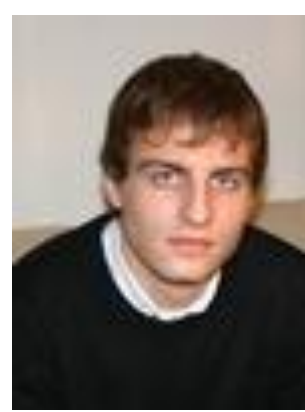

Erki Närep, Bachelor of Science in Engineering, Tallinn University of Technology, Department of Mining.

Previous employment: Trainee, Viru Oil Shale Mine (2010). Laboratory Technician,

limestone mining and processing enterprise OÜ Väo Paas (2012).

Current employment: Eng-Est Translator, Synergium TLS OÜ $(2012$ - ...). Laboratory Assistant, Tallinn University of Technology, Department of Mining. (2013 - ...).

Address: Ehitajate tee 5, 19086, Tallinn E-mail: erki.narep@ttu.ee

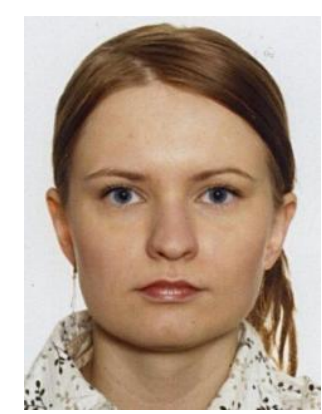

Vivika Väizene is specialist in Department of Mining at Tallinn University of Technology. She obtained her Master degree (MSc) in Geotechnology specialization in mining in 2010. She has been working in Department of Mining since 2007. Her research interests are mining technologies, evaluations of oil shale resources, estimations of oil shale, computer modeling, environmental impacts and protection. She is member of Competence committee for valuating shift foremen and Estonian Mining Society.

E-mail: vivika.vaizene@ttu.ee
Address: Ehitajate tee 5, 19086, Tallinn 